\title{
PROPHYLACTIC OF STRESS FRACTURES OF VERTEBRAE ADJACENT TO TRANSPEDICULAR SCREW FIXATION FOR OSTEOPOROSIS
}

\author{
PROFILAXIA DAS FRATURAS POR ESTRESSE DE VÉRTEBRAS ADJACENTES À FIXAÇÃO \\ COM PARAFUSO TRANSPEDICULAR EM OSTEOPOROSE
}

\author{
PROFILAXIA DE LAS FRACTURAS POR ESTRÉS DE VÉRTEBRAS ADYACENTES A LA \\ FIJACIÓN DE TORNILLO TRANSPEDICULAR EN OSTEOPOROSIS
}

\author{
Igor Basankin, ${ }^{1}$ Vladimir Porkhanov, ${ }^{1}$ Karapet Takhmazyan, ${ }^{1}$ Asker Afaunov, ${ }^{2}$ Dmitril Ptashnikov, $^{3}$ Olga Ponkina, ${ }^{1}$ Marina Tomina, $^{2}$ Sergey $_{\text {Malakhov, }}{ }^{1}$ \\ VLADIMIR SHAPOVALOV ${ }^{1}$ \\ 1. Research Institute Krasnodar Regional Hospital 1, Krasnodar, Russia. \\ 2. Kuban State Medical University, Krasnodar, Russia. \\ 3. Russian Research Institute of Traumatology and Orthopedics named after R. R. Vreden, Saint-Petersburg, Russia
}

\begin{abstract}
Objective: To assess the efficacy and use of vertebroplasty as a prophylactic measure to prevent stress fractures of vertebrae adjacent to transpedicular screw fixation with augmentation for osteoporosis. Methods: An experimental cadaveric study was performed to assess the overall strength of 10 cadaveric blocks of T10-L4 vertebral segments with simulation of L1 fracture and T12-L2 transpedicular 4-screw system with augmentation. T11 and L2 vertebroplasty cranial and caudal to the transpedicular system was performed in 5 blocks in the main group. Stress testing of the blocks was performed by placing them under a vertically directed load until destruction. Results: Vertically directed load on the blocks in the main group $(0.84 \pm 0.39831 \mathrm{kN})$ resulted in T11 vertebrae fractures. Vertebrae with augmentation were resistant to the load in the main group. T10 vertebrae fractures in the blocks of the main group occurred at a load of $1.91 \pm 0.40566 \mathrm{kN}$. Conclusion: 1 . The adjacent T11 vertebra is the weakest vertebra in the anatomical blocks of T10-L4 vertebral segments with simulation of L1 fracture (type A according to the AO/Magerl classification) and the T12-L2 4-screw transpedicular system with augmentation. 2. Bone cement injection into the T11 cranial vertebra adjacent to the level of fixation increases the overall strength of the blocks 3. Vertebroplasty of the overlying vertebra is an effective way to prevent its fracture and in case of osteoporosis. 4. Prophylactic vertebroplasty of the vertebra caudal to the level of fixation is unnecessary due to the insignificant risk of a fracture. Level of Evidence III; Experimental - Quasi experiments
\end{abstract}

Keywords: Spine; Spinal Fracture; Osteoporosis.

\section{RESUMO}

Objetivo: Avaliar a eficácia e o uso da vertebroplastia como medida profilática para prevenir fraturas por estresse das vértebras adjacentes à fixação com parafuso transpedicular com o aumento da osteoporose. Métodos: Foi realizado um estudo cadavérico experimental para avaliar a resistência global de 10 blocos cadavéricos dos segmentos T10-L4 com simulação de fratura de L1 e sistema com 4 parafusos transpediculares em T12-L2 com aumento. A vertebroplastia de T11-L2 cranial e caudal ao sistema transpedicular foi realizada em 5 blocos no grupo principal. Os testes de estresse nos blocos foram realizados aplicando-se carga vertical até ocorrência de fratura. Resultados: A carga vertical sobre os blocos no grupo principal $(0,84 \pm 0,39831 \mathrm{kN})$ resultou em fratura da vértebra T11. As vértebras com aumento foram resistentes à carga no grupo principal. As fraturas da vértebra T10 nos blocos do grupo principal ocorreram com carga de 1,91 $\pm 0,40566$ kN. Conclusão: 1. A vértebra adjacente à T11 é a mais fraca nos blocos anatômicos dos segmentos vertebrais T10-L4 com simulação de fratura de L1 (tipo A de acordo com a classificação AO/Magerl) e do sistema transpedicular com 4 parafusos T12-L2 com aumento. 2. A injeção de cimento ósseo na vértebra adjacente à $T 11$ em sentido cranial ao nível de fixação aumenta a resistência global dos blocos. 3. A vertebroplastia da vértebra sobrejacente é uma forma eficaz de prevenir a fratura nos casos de osteoporose. 4. A vertebroplastia profilática da vértebra caudal ao nível de fixação é desnecessária devido ao risco insignificante de fratura. Nível de Evidência III; Experimental Quase experimentos.

Descritores: Coluna Vertebral; Fraturas da Coluna Vertebral; Osteoporose.

\section{RESUMEN}

Objetivo: Evaluar la eficacia y el uso de la vertebroplastia como medida profiláctica para prevenir fracturas por estrés de las vértebras adyacentes a la fijación con tornillo transpedicular con aumento de la osteoporosis. Métodos: Se realizó un estudio cadavérico experimental para evaluar la resistencia global de 10 bloques cadavéricos de los segmentos T10-L4 con simulación de fractura de L1 y sistema con 4 tornillos transpediculares en Th12-L2 con aumento. La vertebroplastia de T11-L2 craneal y caudal al sistema transpedicular se realizó en 5 bloques en el grupo principal. Los tests de estrés en los bloques fueron realizados aplicándose carga vertical hasta la ocurrencia de fractura. Resultados: La carga vertical sobre los bloques en el grupo principal (0,84 $\pm 0,39831 \mathrm{kN}$ ) resultó en fractura de la vértebra T11. Las vértebras con aumento fueron resistentes a la carga en el grupo principal. 
Las fracturas de la vértebra T10 en los bloques del grupo principal ocurrieron con carga de 1,91 \pm 0,40566 kN. Conclusión: 1. La vértebra adyacente a T11 es la más débil en los bloques anatómicos de los segmentos vertebrales T10-L4 con simulación de fractura de L1 (tipo A según la clasificación AO/Magerl) y del sistema transpedicular con 4 tornillos T12-L2 con aumento. 2. La inyección de cemento óseo en la vértebra adyacente a la 711 em sentido craneal al nivel de fijación aumenta la resistencia global de los bloques 3. La vertebroplastia de la vértebra suprayacente es una forma efectiva de prevenir la fractura en los casos de osteoporosis. 4. La vertebroplastia profiláctica de la vértebra caudal al nivel de fijación es innecesaria debido al riesgo no significativo de fractura. Nivel de evidencia III; Experimental - Cuasi experimentos.

Descriptores: Columna Vertebral; Fracturas de la Columna Vertebral; Osteoporosis.

\section{INTRODUCTION}

Osteoporosis-related vertebral fractures are a serious problem. Longer life expectancy among the population has led to a steady increase in the number of the patients with this problem. ${ }^{1}$ Pedicle screw fixation (PSF) with augmentation is the main method used to treat thoracic and lumbar spine fractures with significant compression of vertebral bodies and deformity.

It is known that PSF with augmentation provides significantly greater strength compared to PSF without augmentation ${ }^{2-4}$. It also prevents transpedicular system instability over a long-term period. However, the use of two- and more segment PSF with augmentation for the surgical treatment of osteoporosis-related vertebral fractures has shown that the load on adjacent vertebrae increases, sometimes leading to fractures. ${ }^{5-7}$ Cadaveric and clinical studies of patients with extended PSF showed vulnerability of the vertebrae cranial to the transpedicular system to stress fracture in activities of daily living. ${ }^{8,9}$ The search for optimal measures to prevent such complications is a challenge for modern vertebrology.

Objective: The study was performed to assess the efficacy and use of vertebroplasty as a prophylactic measure to prevent stress fractures of vertebrae adjacent to PSF with augmentation for osteoporosis.

\section{METHODS}

The cadaveric material for this study was obtained from ten females aged over 66 years, who had died from various somatic diseases. Blocks of T10-L4 vertebral segments (7 vertebrae) were used. A Protocol of acceptance was granted by the Ethics Committee under no. 46. An Informed Consent Form was signed by relatives of all the participants.

The vertebrae with intervertebral discs and capsular-ligament apparatus were intact. The paravertebral muscles were completely removed.

All the blocks were submitted to $2 \mathrm{D}$ X-ray radiography, CT and CT-densitometry before the experiment. CT and CT-densitometry of the blocks were performed using a 128-slice "ST SOMATOM SENSATION 24 OPEN" CT scanner. Inclusion criteria for the study were: no destructive changes in the spine, no significant coronal or sagittal deformities, no signs of ankylosing spondylitis, and the presence of signs of osteoporosis in the X-ray and densitometry (T-score $<-2.5$ ).

Simulation of unstable $\mathrm{L} 1$ fracture (type $\mathrm{A}$ according to the $\mathrm{AO}$ / Magerl classification) with up to $40 \%-50 \%$ vertebral body destruction in the cranial part was performed in all the blocks. This was achieved by resection of the cranial part of the $L 1$ vertebral body with the T12-L1 intervertebral disc. Thus, experimental conditions were created that were as close as possible to real cases where there is kyphotic deformation with loss of support ability of the ventral part of the vertebra. The L1 vertebra body was chosen as according to statistics, this is the vertebra that is fractured more often. ${ }^{10}$

T12-L2 4-screw transpedicular fixation with augmentation was simulated in all the blocks after L1 fracture. To strengthen the screws, 7-8 $\mathrm{ml}$ of bone cement was injected into each vertebra. Correct placement of the screws was monitored with a "Siemens Arcadis" Z-arm and "Philips Duo Diagnost" X-ray upon completion of the fixation. Thus, two vertebrae above and below the transpedicular system remained intact in each block.

Next, all the blocks were divided in 2 groups of 5 blocks each.

Group 1, the control group, included the blocks with simulated L1 fracture and T12-L2 4-screw PSF with augmentation. Two vertebrae above and below the transpedicular system remained intact.

Group 2, the main group, included the same blocks but with vertebroplasty of T11 and L3. A 13G needle was used to inject 7-8 $\mathrm{ml}$ of bone cement (25\% of the vertebra) into each vertebra. ${ }^{11}$ Occupation density was controlled by X-ray.

The anatomical blocks of the vertebral segments from the main and control groups prepared in this way were subjected to a vertically directed mechanical load to determine the overall strength. The experiments were performed in the test laboratory of the Central Scientific Research Institute of Traumatology and Orthopedics (Moscow) using a universal servo-hydraulic testing machine "Walter + bay ag" LFV-10-T50 (Switzerland).

The tested blocks of vertebral segments were fixed on the special platforms between converging plates of the testing machine. The proximal platform assembly, fastening the cranial vertebra of the tested block, was attached to the compression sensor, which was rigidly attached to the movable plate of the testing machine. The distal platform assembly, fastening the caudal vertebra of the tested block, was fixed in a three-jaw chuck, which was attached to the axis of the motor rigidly fixed on the immovable plate. The distance between the plates was set in accordance with the vertical dimensions of the tested blocks (Figure 1). The zero position was set on the sensor before the experiment started. The testing machine was turned on in Compression Mode. Vertically directed increasing load was then applied. The plates converged at speed of $5 \mathrm{~mm} / \mathrm{min}$. The compression rate was from 0 to $3-5 \mathrm{kN}$.

Visual observation initially indicated the appearance of insignificant kyphotic deformation cranial to the level of PSF under the influence of increasing load. After that, there was a gradual destruction of the tested blocks accompanied by the typical sound and further increasing deformation without a proportional increase of the load. The data obtained were processed on a computing unit of the testing machine. The deformation parameters, depending on the load applied to the blocks, were recorded in the form of diagrams with the line of vertical load $(\mathrm{N})$ and the line of compression deformation $(\mathrm{mm})$.

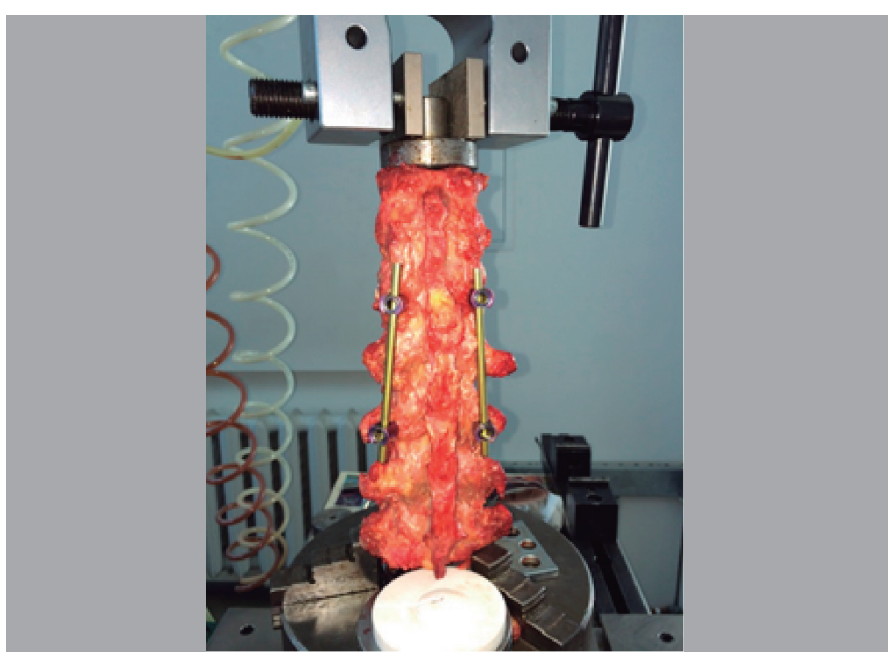

Figure 1. The anatomical block of vertebral segments before the experiment. 
The experiment revealed the force of vertical load on the blocks required to cause initial fractures. The fractures were presented in the diagrams as graphical line oscillations, showing dependence of compression deformation on the applied load. These parameters characterize the overall strength of the tested anatomical blocks of the vertebral segments. The angular deformations of the vertebral segments were digitally photographed and also video recorded. The diagrams obtained were used to compile tables for further analysis. The discreteness of the load in the tables was 20 $\mathrm{N}$. The quantitative characteristics of the experiment results were subjected to statistical processing to determine the standard error of the mean values.

When the experiment was completed, all the blocks were submitted to control X-ray radiography and CT scanning to visualize the fractures. Placement of the transpedicular system was controlled to identify signs of instability and find fractures in the blocks with implanted screws and fractures of the vertebrae cranial or caudal to the transpedicular system. The data from the X-ray radiography were compared with the diagrams showing the fracture.

\section{RESULTS}

$X$-ray radiography and CT scanning of the blocks did not show signs of transpedicular system instability in any of 10 experiments in both groups. Also, fractures of the vertebrae with implanted screws and fractures or instability of transpedicular system elements were not revealed.

In group 1 (control), initial graphic oscillations indicating the fracture were detected in the range of 0.78-0.94 (0.84 \pm 0.39831$)$ kN (Figure 2). A further increase of the load up to 1.24-1.6 (1.47 \pm $0.39831) \mathrm{kN}$ was accompanied by graphic imaging of some more oscillations and the appearance of visual kyphotic deformation, indicating more severe destruction of the blocks.

$\mathrm{X}$-ray radiography and CT scanning performed after the testing revealed a fracture of the T11 vertebra body adjacent to the transpedicular system in all the blocks of the control group. There were no radiographic signs of a fracture of the other vertebrae in the control group. CT-scans before and after the experiment in the control group are shown in Figure 3.

The same experiment was performed in group 2 (main) and the data obtained differed significantly from those in group 1 (control). The first graphical oscillations indicating the appearance of fracture were detected in the range of 1.78-2.05 $(1.91 \pm 0.40566) \mathrm{kN}$. Signs of more severe destruction of the vertebra were recorded in the range of 2.12-2.88 (mean $2.51 \pm 0.40566$ ) $\mathrm{kN}$

The diagram in Figure 4 shows how tested block deformation depends on the applied vertical load and shows appearance of a T10 vertebral body fracture above the vertebra with augmentation.

The diagram shows that the gradual increase of the load up to $2.05 \mathrm{kN}$ does not lead to any oscillations. The first graphical oscillation indicating appearance of the first microfracture of the

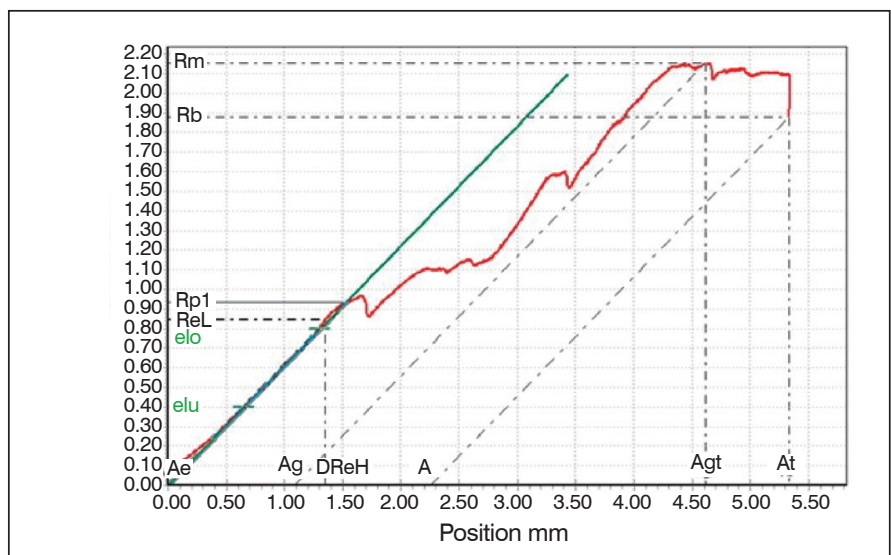

Figure 2. The diagram of the tested block deformation dependency on the applied vertical load in the control group.

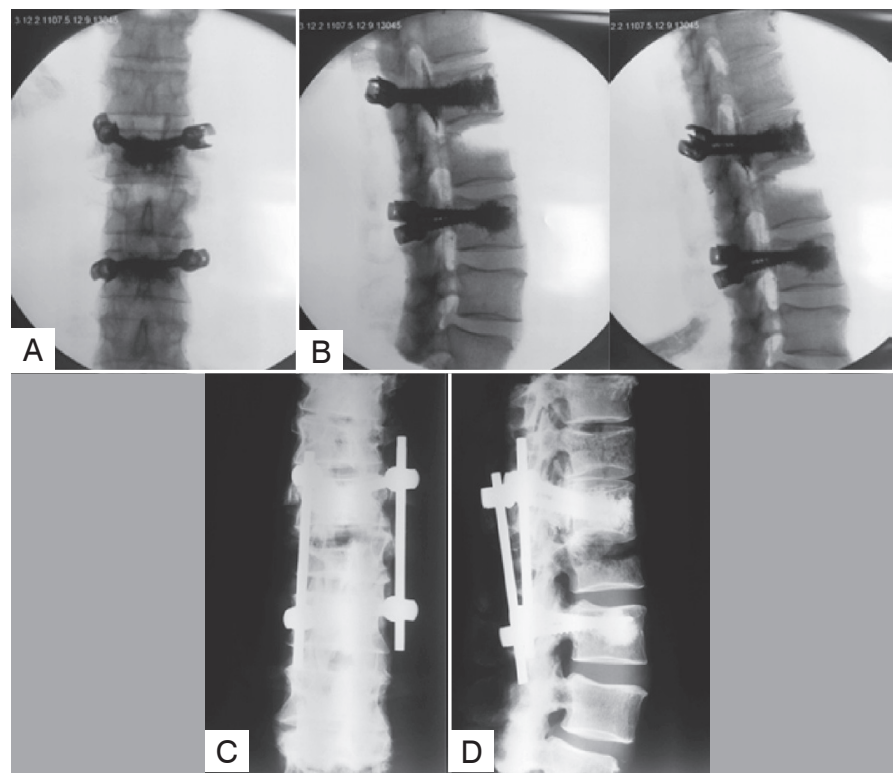

Figure 3. CT scans of the blocks in the control group (non-augmented T11 and $L 3$ adjacent to the fixed blocks). (A,B) CT scans of the blocks in the control group before the experiment. T12 and $\mathrm{L} 2$ with augmentation, $\mathrm{L} 1$ cranial part with the overlying disk resection. (C,D) CT scans of the blocks in the control group after the experiment. T11 fracture is diagnosed as the loss of vertical height of the vertebra and presence of fracture lines in the lateral plane. (D) loss of vertical height of the vertebra on its left side in the anterior plane (C).

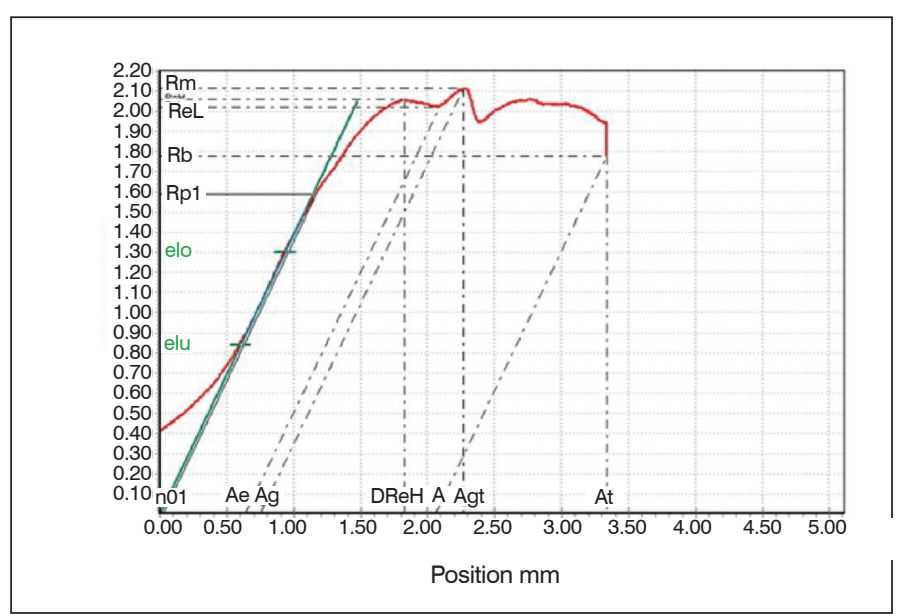

Figure 4. The diagram of the tested block deformation dependency on the applied vertical load in the main group.

vertebra body is recorded when the level of load is 2.05-2.05 $\mathrm{kN}$. Then, after a minor increase of the load, a greater graphical dip in the range of 2.14-1.94 $\mathrm{kN}$ is recorded. A further increase of the load shows more severe destruction of the vertebral trabecular bone.

Subsequent $\mathrm{X}$-ray radiography showed that $\mathrm{T} 11$ and $\mathrm{L} 3$ vertebrae with augmentation, which were adjacent to the transpedicular system, were resistant to the mechanical load. Fractures did not occur in any of these vertebrae. A fracture of the T10 vertebra, located above the T11 vertebra with augmentation, was diagnosed in all five blocks of the main group.

CT-scans of the vertebral bodies with augmentation adjacent to the transpedicular system made before and after the experiment in the main group are presented in Figure 5.

Data obtained after the testing are presented in Table 1.

The indicators of the overall resistance of the tested blocks to vertically directed mechanical load in both groups necessary for the appearance of fractures are shown graphically in Figure 6. 


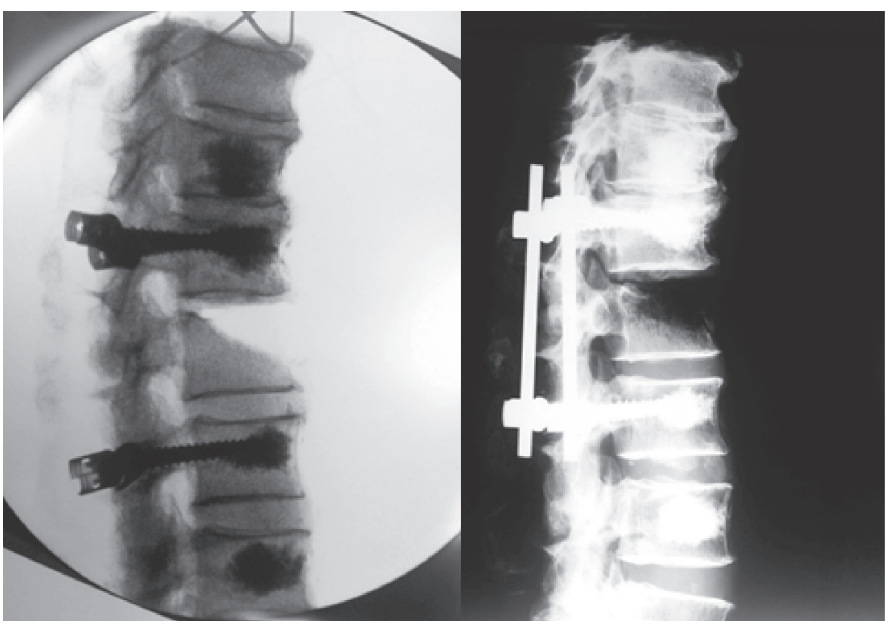

Figure 5. CT scans of the blocks in the main group (augmented T11 and $\mathrm{L} 3$ adjacent to the fixed blocks). (A) CT scans of the blocks with T11 and L3 augmentation before the experiment. (B) CT scans of the blocks in the main group after the experiment. Augmented T11 is resistant to the load. A fracture of the cranial T10 overlying the vertebra with augmentation.

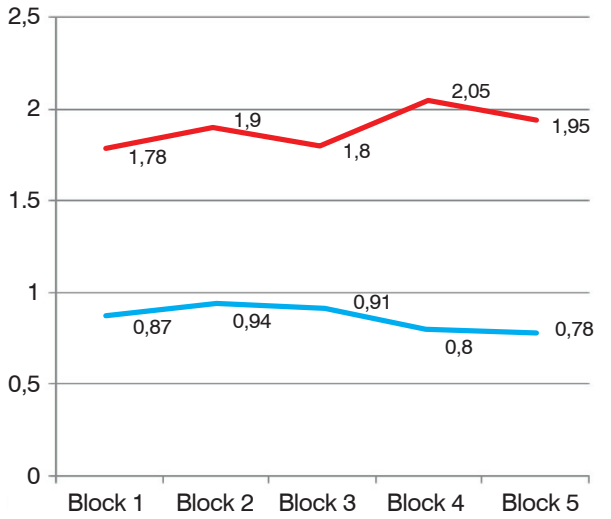

With VP W W W W

Figure 6 . The indicators of the overall resistance of the tested blocks to vertically directed mechanical load in the control and main groups.

Table 1. Groups of the tested blocks of vertebra segments. Load indicators for a vertebra fracture.

\begin{tabular}{|c|c|c|c|c|c|c|}
\hline Group & Tested blocks & Gender, Age & T-score & Fracture signs & Severe deformation & Fractured vertebra \\
\hline \multirow{3}{*}{$\begin{array}{c}\text { Group } 1 \\
\text { (without prophylactic } \\
\text { vertebroplasty) }\end{array}$} & block 3 & Fem. 75 y. & 3.48 & 0.91 & 1.45 & T11 \\
\hline & block 5 & Fem. 80 y. & 3.40 & 0.78 & 1.24 & T11 \\
\hline & average & \multicolumn{3}{|c|}{$0.84 \pm 0.39831 \mathrm{kN}$} & \multicolumn{2}{|c|}{$1.47 \pm 0.39831 \mathrm{kN}$} \\
\hline \multirow{4}{*}{$\begin{array}{c}\text { Group } 2 \\
\text { (with prophylactic } \\
\text { vertebroplasty) }\end{array}$} & block 1 & Fem. 63 y. & 2.51 & 1.78 & 2.12 & T10 \\
\hline & block 4 & Fem. 79 y. & 3.36 & 2.05 & 2.78 & T10 \\
\hline & block 5 & Fem. 67 y. & 2.67 & 1.95 & 2.74 & T10 \\
\hline & average & \multicolumn{3}{|c|}{$1.91 \pm 0.40566 \mathrm{kN}$} & \multicolumn{2}{|c|}{$2.51 \pm 0.40566 \mathrm{kN}$} \\
\hline
\end{tabular}

\section{DISCUSSIONS}

Analysis of the data obtained shows that gradually increasing the vertically directed load on the anatomical blocks of the vertebral segments in the control group initially leads to the appearance of an insignificant kyphotic deformation. This is mainly due to the compression at the T11-T12 level. The ventral side of T11 is biomechanically the most resistant to further increase of the vertically directed load. As a result, a fracture of the ventral side of T11 occurs at the load of 0.78-0.94 kN. A further increase of the load results in a more severe destruction of the vertebral trabecular bone, which is shown in the diagram in the form of dips indicating further fractures that increase and cause significant kyphotic deformation. Thus, the testing of the blocks in the control group showed that the ventral part of T11 vertebra located directly above the transpedicular system is the least resistant to the vertically directed load.

The blocks in the main group underwent the same testing and no fractures occurred in $\mathrm{T} 11$ vertebra with augmentation. The blocks resisted the load up to 1.78-2.05 kN, which was as 1.7-2.3 times higher as in the control group. There were fractures of non-cemented T10 vertebrae that were above the vertebrae with augmentation (T11). Thus, vertebroplasty of the overlying T11 vertebrae is an effective way to prevent its fracture and it can be considered a preventive measure against a stress fracture and proximal kyphosis over the blocks of vertebral segments.

\section{CONCLUSIONS}

1. The adjacent T11 vertebra is the weakest vertebra in the anatomical blocks of T10-L4 vertebral segments with simulation of $L 1$ fracture (type $A$ according to the AO/Magerl classification) and T12-L2 4-screw transpedicular system with augmentation; 2. Bone cement injection into T11 cranial vertebra adjacent to the level of fixation increases the overall strength of the blocks of T10-L4 vertebral segments with the simulation of L1 fracture (type A according to the AO/Magerl classification) and T12-L2 4-screw transpedicular fixation with augmentation 1.7-2.3-fold; 3. Vertebroplasty of the overlying vertebra is an effective way to prevent its fracture and in the case of osteoporosis, it can be considered a preventive measure against a stress fracture and proximal kyphosis over fixed vertebral segments; 4. Prophylactic vertebroplasty of the vertebra caudal to the level of fixation is unnecessary due to the insignificant risk of a fracture.

All authors declare no potential conflict of interest related to this article.

CONTRIBUTION OF THE AUTHORS: Each author made significant individual contributions to this manuscript. IB (0000-0003-3549-0794)* and VP $(0000-0003-2732-2133)^{\star}$ were the main contributors to the drafting of the manuscript. IB, AA (0000-0001-7976-860X)*, KT (0000-0003-4146-6790)*, DP (0000-0001-5765-3158), VS (0000-0003-4556-251X)* and SM (0000-0002-5315-1713) performed the surgery, followed up the patients, and gathered clinical data. VS and MB (0000-0001-9388-5220) evaluated the data from the statistical analysis. AA, DP and OP (0000-0002-2918-8129) performed the literature search and review of the manuscript, and contributed to the intellectual concept of the study. *ORCID (Open Researcher and Contributor ID) 


\section{REFERENCES}

1. Yang Z, Griffith JF, Leung PC, Lee R. Effect of Osteoporosis on Morphology and Mobility of the Lumbar. Spine (Phila Pa 1976). 2009;34(3):115-21.

2. Afaunov A, Basankin I, Takhmazyan K, et.al. Outcomes analysis of transpedicular instrumentation with augmentation for the treatment of osteoporotic thoracolumbar fractures. IV Interregional conference Future development of vertebrology: innovative technologies to treat spine and spinal marrow related diseases and fracture. Novosibirsk; 2013. 10-6.

3. Basankin I, Takhmazyan K, Afaunov A, Ptashnikove DA, Ponkina NS, Gavryushenko4 NS, et.al. Method for preventing fractures of adjacent vertebrae during transpedicular fixation in osteoporosis. Hirurgia pozvonochnika. 2016;13(3):8-14.

4. Burval DJ, McLain RF, Milks R, Inceoglu S. Primary Pedicle Screw Augmentation in Osteoporotic Lumbar Vertebrae: Biomechanical Analysis of Pedicle Fixation Strength. Spine (Phila Pa 1976). 2007:32(10):1077-83

5. Byvaltsev V, Kalinin A. Analysis of results of reduction of kiphotic deformation by minimally invasive transpedicular stabilization in patients with traumatic compression fractures of thoracolumbar localization. Vestnik Hirurgii. 2017;176(5):64-71.

6. Lau D, Clark AJ, Scheer JK, Daubs MD, Coe JD, Paonessa KJ, et.al. Proximal Junc- tional Kyphosis and Failure After Spinal Deformity Surgery: A Systematic Review of the Literature as a Background to Classification Development. Spine (Phila Pa 1976). 2014;39(25):2093-102.

7. Fernández-Baíllo N, Sánchez Márquez JM, Pérez-Grueso FJS, García Fernández A. Proximal Junctional Vertebral Fracture-subluxation after Adult Spine Deformity Surgery. Does vertebral augmentation avoid this complication? A case report. Scoliosis. 2012;7:16.

8. Hassanzadeh H, Jain A, El Dafrawy MH, Ain MC, Mesfin A, Skolasky RL, et al. Three-Column Osteotomies in the Treatment of Spinal Deformity in Adult Patients 60 Years Old and Older: Outcome and Complications. Spine (Phila Pa 1976). 2013:38(9):726-31.

9. Martin C, Skolasky RL, Mohamed AS, Kebaish KM. Preliminary Results of the Effect of Prophylactic Vertebroplasty on the Incidence of Proximal Junctional Complications After Posterior Spinal Fusion to the Low Thoracic Spine. Spine Deform. 2013;1(2):132-8.

10. Lehman RA Jr, Paik H, Eckel TT, Helgeson MD, Cooper PB, Bellabarba C. Low Lumbar Burst Fractures: A Unique Fracture Mechanism sustained in our current overseas conflicts. Spine J. 2012;12(9):784-90.

11. Manukovskii DA. Vertebroplasty for spine pathology treatment. Abstract of a doctoral thesis, Sain-Petersburg; 2009 